\title{
SWOT Analysis in the Development Tourism of Kampung Topeng Malangan
}

\author{
$1^{\text {st }}$ M. Nurfahrul Lukmanul Khakim \\ History Departement \\ State University of Malang \\ Malang, Indonesia \\ moch.nurfahrul.fis@um.ac.id \\ $2^{\text {nd }}$ Ulfatun Nafi'ah \\ History Departement \\ State University of Malang \\ Malang, Indonesia
}

\author{
$3^{\text {rd }}$ Muhammad Bahtiar Syarifudin \\ History Departement \\ State University of Malang \\ Malang, Indonesia
}

\author{
$4^{\text {th }}$ Kiki Nur Azizah \\ State University of Malang \\ Indonesia
}

\begin{abstract}
The development of tourism in Indonesia can be said to increase rapidly. The majority of Indonesia's population likes to travel. Therefore, many opening of new tourist sites in various places. One of them is the tourism village of Kampung Topeng Malangan (Malangan Mask Village) which is located in Baran Hamlet, Tlogowaru Village, Kedungkandang District. The opening of tourist sites needs to consider the advantages and disadvantages of the environment. The Malangan Mask Village was established to empower poor villagers. SWOT analysis, in this case, can help see the advantages and disadvantages of these locations as tourist attractions. Tourism of Kampung Topeng Malangan has a strength of the beauty of attractions, Weakness, which is difficult road access, Opportunities, which emphasizes local wisdom, Threat, which is still low public awareness. Malangan Mask Village is suitable as tourismbased tourism, cultural and nature tourism destination. Education and outreach to overcome obstacles and threats in the Malangan Mask Village need to be done in stages and humanist by tourism stakeholders. The management of Topeng Malangan village tourism still needs to be improved properly by the government and the surrounding community by providing easy road access, improving tourism facilities and promoting it in mass media and social media.
\end{abstract} tourism

Keywords: SWOT analysis, Kampung Topeng Malangan,

\section{INTRODUCTION}

Malang is the second-largest city in East Java after Surabaya. In its development, the city of Malang has various designations and one of them is a tourist city. As a tourist city, Malang has a variety of interesting tourist destination destinations for tourists to visit, such as nature, religion, culture, history, and education. Even as time goes by more and more opening of new tourist attractions in Malang. This happens because, in addition to the city of Malang known as a tourist city, Malang is also known as the city of education. Where several State Universities cause an increase in the number of residents from outside Malang. Therefore, it can be utilized as a tourism business opportunity, seeing the many millennial generations who live in Malang.

Tourism is one of the important things for a country. With tourism, a country or more specifically the area where the tourist attraction gets income from the income of each tourist attraction. The development of the tourism sector in a country will attract other sectors to develop because its products are needed to support the tourism industry, such as agriculture, animal husbandry, plantations, folk crafts, increased employment opportunities, etc. [1].

Tourism in the city of Malang is growing rapidly from year to year. The development of tourism in the city of Malang can be seen from the formation of villages as tourist attractions. Some villages in the city of Malang have been successfully made as attractive tourist villages to visit with various advantages of each. In addition to Jodipan Tourism Village (KWJ) and Tridi Village which are well-known as tourist villages in Malang, new villages or tourism villages have also been present with the concept of local cultural wisdom, Malangan Mask.

Malangan Mask Village is a tourist village located in the Baran Hamlet, Tlogowaru Village, Kedungkandang District. Malangan Mask Village which became a tourist village was previously one of the villages in the form of implementation of the government program of the Ministry of Social Republic of Indonesia, Directorate General of Social Rehabilitation called 


\section{RESULTS AND DISCUSSION}

the Desaku Menanti program. The program emerged, because of the encouragement of the government's desire to rehabilitate street children, homeless people, and beggars [2].

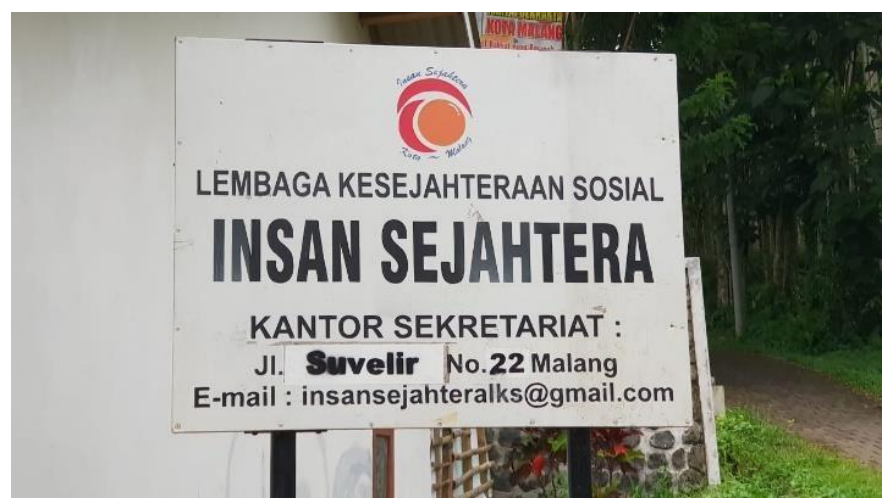

Fig. 1. Social Welfare Institions who support this village

From the implemented program, a new idea emerged, namely by making the village a tourist village that had a positive impact on local culture, visitors and especially homeless people and beggars themselves who occupied the area. Inauguration of my village waiting to become a tourist village makes the rehabilitation program for homeless and beggars more successful by empowering them into positive activities as well as making useful work that also has positive work for a better life than before. This can be said as the use of the community in the development of a tourist village, which later will also benefit the local community itself [3].

\section{METHOD}

This type of research used in this research is descriptive qualitative. [4] explains descriptive qualitative research is a systematic and subjective approach in explaining everything in the field (empirical) and oriented to efforts to understand the phenomenon as a whole. Data collection techniques we do by observation of the location. In this study the source of information obtained from the Village Mask Malangan. The analytical tool used is the SWOT analysis (Strength, Weakness, Opportunities, Threat). SWOT analysis is one method of developing conditions and evaluating a problem, project or business concept based on internal and external factors, namely Strength, Weakness, Opportunities, Threat, this method is most often used in business evaluation methods to find a strategy that will be done. Personal documentation photo observations on February 23, 2019. SWOT analysis only describes the situation that happened not solving the problem. However, from this analysis, we can find out the obstacles that will be faced and can solve the problems that occur [5].
Kampung Topeng Malangan is a distinctive culture of Malang, wherein the beginning the Malangani Mask was used as a puppet mask and as an accessory in Malang's distinctive dancing. because the puppets or dance people use masks with certain characteristics, it is called the Malaling Mask. [6] states that tourism areas are areas with a certain area that are built or provided to meet tourism needs. This Malangani Mask Tourism tour includes a tourist area located in the Baran Hamlet, Tlogowaru Village, Kedungkandang District, Malang Regency.

However, in today's Kampung Topeng Malangan is increasingly less in demand by the community. Because of technological developments, most people turn to more modern entertainment media [7]. The establishment of the Malangan Mask Village itself is also based on these reasons. Where besides empowering the homeless and beggars, it also preserves the local wisdom of the people of Malang. Therefore, in this case the researcher wants to conduct a SWOT analysis-based tourism village study in the Malangan Mask Village as an evaluation of the development of the tourism village.

\begin{tabular}{|l|l|}
\hline \multicolumn{2}{|c|}{ SWOT MATRIX } \\
\hline Strenght & Attractive and fresh village \\
\hline Weakness & Hard acces \\
\hline Opportunities & Support local traditions \\
\hline Treat & Low skill of the local \\
\hline
\end{tabular}

The SWOT analysis in this paper is an analysis used to determine the potential of a place as a tourist destination. Because as explained at the beginning that the Malangan Mask Village is the government's idea to empower homeless people and beggars. With the existence of the Mask Village is expected to help the homeless and beggars to get a better life and also have a decent job.

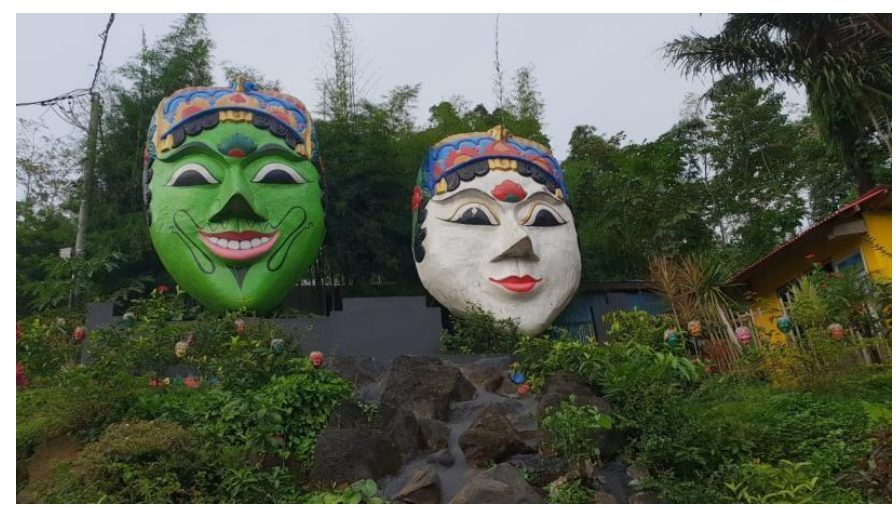

Fig. 2. Kampung Topeng Malangan (Malangnesse Village Mask) 
Strenght, in the Malangan Mask Village as a tourist village that is an unspoiled place, far from the noise of the city. Suitable for tourists who are looking for cool air and calm from the bustling city life. Besides, the strength in the development of this tourist village is by empowering the homeless and beggars (homeless and beggars) to be directed towards creation and production as a provision for a better life. The existence of this tourist village can also provide income for the village itself. One of them is the entrance fee for visitors worth five thousand rupiahs per person (per ticket). But this village also provides feedback for visitors in the form of self-produced snacks. Also in that village, there is already a souvenir shop that visitors can buy as souvenirs. The existence of this village can also be a means of learning and preservation for local wisdom. Learning, especially local wisdom that is interesting and up-to-date, then fosters community interest to study history [8].

Weakness, access to this village can be quite difficult. One of them is some damage to the asphalt road and there is steep descent. Road directions to this village are also not available. This village can be said to be classified as a place that is very far from the hustle of the city. Therefore, if there are no road directions it will make visitors difficult to find the location of the village. Some tourism facilities and facilities in this village were also seen damaged. Means of tourism are the basic completeness of a tourist attraction area needed to serve the needs of tourists to be comfortable in enjoying their vacation [9]. This clearly shows that there are deficiencies in maintaining tourism facilities and facilities.

Awareness to maintain the cleanliness of tourism sites is also still lacking. Though in the village area has provided several places for garbage collection. The plants that are in the tourism sites are also classified as poorly maintained to make these plants grow wild and not beautiful. The village requires counseling about education and continuing behavior education due to the presence of population behavior that is classified as not good for children. Kampung Topeng Malangan also has not provided a place to stay or stay temporarily like a homestay. [10] states three main needs that must be met by an area to become a tourist destination: having uniqueness or interesting objects, easily accessible by land transportation modes, providing facilities for temporary residence. Malangan Mask Village has fulfilled the first needs but failed to fulfill the second and third needs.

Opportunities, as a tourist destination in the city of Malang, the village already has a great opportunity to become a place of tourism. Apart from being a tourism area, the village also has another ability, namely as a place for educational advice and preservation of unfortunate local wisdom, the Mask of Malangani. Another opportunity the village has is as a place of empowerment for people who live around the village to improve their economic lives. Damardjati (2001: 38) states ecotourism is a business and tourism activity to the natural environment area, accompanied by full awareness of the existence of high responsibility for the preservation of the natural environment and improving the welfare of the local population [14]. Malangan Mask Village is also suitable for ecotourism because it has a green and cool natural environment. This opportunity can be utilized and developed to manage this tourist attraction as an environmentally friendly cultural village.

Threat, in the tourism Kampung Topeng Malangan can be seen from the lack of moral awareness that is still present in the village community can make a threat to the place of tourism itself. This is because near the village the establishment of a boarding school that functions as a place of education. It is feared that it will cause friction due to moral differences that develop in both. Access to the village which is also relatively difficult to reach makes the village threatened deserted from tourist visitors. Heritage tourism focuses on both intangible traditions and tangible sites [11]. [12] state that cultural tourism is a tour that is carried out to find information or learn habits and customs, ways of life, culture, and art, as well as historical activities with a group of people by conducting direct observations to the location of the source. As a cultural tourism object, Malangan Mask Village stands in an environment that already has another stronger culture. The Islamic culture adopted by the majority of villagers could threaten the development of the Kampung Topeng Malangan if it was not dealt with collaboratively and humanist studies, socialization, and cultural mediation. Also the low skills, consistency and education of local residents to substain the tourism.

From the SWOT analysis above, stakeholders related to Malangan Mask Village can take strategic steps to manage this tour. One of them is by providing easy and safe road access to this tour because the location is quite far from the city center. This needs to be in the spotlight of the government because it is difficult to find tourism support facilities such as gas stations or restaurants. The strategic step that must be taken by the Regency Government is to assign historians, anthropologists, and cultural figures to explore and enhance the other potentials of the Malangan Mask Village [14]. This is important to increase the tourist attraction of Malangan Mask Village in the future so that these attractions can continue to be used sustainably. Tourism managers also need to promote the Malangan Mask Village through print and mass media to attract investors' attention to the development and increase the number of tourists

\section{CONCLUSION}

The development of tourism villages in today is very much in demand. Because by making the village as a tourist spot, it will benefit the village community. However, this cannot be done just like that. It is necessary to consider the advantages and disadvantages of the location that will be used as a tourist spot. Because villages that are tourist sites must be supported by economic factors or cultural preservation. Based on the SWOT analysis, Malangan Mask Tourism Village has a strength of the beauty of village, Weakness is difficult road access, 
Opportunities is emphasizes local wisdom, Threat is still low skill to maintain the tourisme.

\section{REFERENCES}

[1] Suarto, E. "Pengembangan Objek Wisata Berbasis Analisis SWOT". Jurnal Spasial, Vol. 3, Nomor 1, Februari 2017.

[2] Subadyo, A. T. 2018. "Pengembangan Dusun Baran, Tlogowaru, Kedungkandang Sebagai Kampung Wisata Topeng di Kota Malang". Jurnal ADIMAS UNMER Malang, Vol. 03, Nomor 1, Juni 2018.

[3] Purnamasari, Andi Maya. "Pengembangan Masyarakat Untuk Pariwisata Di Kampung Wisata Toddabojo Provinsi Sulawesi Selatan”. Jurnal Perencanaan Wilayah dan Kota, Vol. 22 No. 1, April 2011, hlm.49-64.

[4] Sugiyono. 2008. Metode Penelitian Pendidikan. Bandung: Penerbit Alfabeta

[5] Freddy, Rangkuti. 2014. Analisis SWOT Teknik Pembeda Kasus Bisnis. Jakarta: PT Gramedia Pustaka Utama.

[6] Atmaja, Ida Bagus Yoga. 2002. Ekowisata Rakyat: Lika-Liku Ekowisata di Tenganan, Pelaga, Sibetan dan Nusa Ceningan Bali. Denpasar: Wisnu
[7] Astrini, Wulan dkk. "Semiotika Rupa Topeng Malanganan (Studi Kasus: Dusun Kedungmonggo, Kec. Pakisaji, Kabupaten Malang)". Jurnal RUAS, Volume 11 N0 2, Desember 2013, ISSN 1693-3702.

[8] Khakim, M. N. L. (2016). Telaah Penulisan Karya Sastra sebagai Refleksi Sumber Pembelajaran Sejarah. Jurnal Sejarah Dan Budaya, X(1), 89-94. https://doi.org/http://dx.doi.org/10.17977/um020v10i12016p089

[9] Bafadhal, Aniesa Samira. 2018. Perencanaan Bisnis Pariwisata (Pendekatan Lean Planning). Malang: UB Press

[10] Pendit, Nyoman S. 2003. Ilmu Pariwisata. Jakarta: PT Pradnya Paramita

[11] Smith, Melanie, dkk. 2010. Key Concepts in Tourist Studies. London: Sage

[12] Simanjuntak, Bungaran Antonius, dkk. 2017. Sejarah Pariwisata Menuju Perkembangan Pariwisata Indonesia. Jakarta: Yayasan Obor

[13] Darmadjati, R. S. 2001. Istilah-istilah Dunia Pariwisata. Jakarta: Penerbit Pradnya Paramita

[14] Khakim, M. N. L., Ulfa, M., Putri, U., \& Budi, N. A. (2019). URGENSI PENGELOLAAN PARIWISATA KAMPUNG HERITAGE. Jurnal Teori Dan Praksis Pembelajaran IPS, 4(1), 15-22. https://doi.org/http://dx.doi.org/10.17977/um022v4i12019p015 